\title{
Conexões entre artes de rua, criatividade e profissões: circuitos e criações de Tamara Alves
}

Connections between street art, creativity and professions: Tamara Alves' circuits and creations

\author{
Glória Diógenes * \\ *Universidade Federal do Ceará - Fortaleza, CE, Brasil \\ gloriadiogenes@gmail.com \\ https://orcid.org/0000-0002-7494-8553
}




\title{
Resumo
}

Este artigo é parte de uma etnografia realizada em Lisboa sobre arte urbana e graffiti. O texto evidencia as fluidas e porosas fronteiras que se desenham entre conexões e produções da arte urbana. Como caso exemplar, segui a trajetória da writer portuguesa Tamara Alves, que, além de "artista de rua", se autoidentifica como designer gráfica, tatuadora, performer e DJ. Notei que, na medida em que é dado ao artista a palavra possível de cerzir o underground com outros domínios singulares de atuação, ele passa a operar no circuito entre um dentro e um fora do mercado, entre trabalho e prazer, tal qual sinaliza o pontilhismo das experimentações efetuadas por Tamara Alves. Concluo, de modo provisório, que as divisas entre o tempo de fruição da vida e o relativo ao do trabalho cada vez mais se estreitam no âmbito das profissões consideradas criativas, configurando novas agências e modulações entre trabalho e arte.

Palavras-chave: arte urbana; experimentação profissional; circuitos sobrepostos; criatividade.

\begin{abstract}
This paper is part of an ethnography carried out in Lisbon on urban art and graffiti during the year 2013. The text highlights the fluid and porous borders that are drawn between the multiple connections and productions of urban art. As an exemplary case, we followed the vocational training path of Portuguese writer Tamara Alves, who in addition to being a "street artist" identifies herself as a graphic designer, tattoo artist, performer and DJ. We notice that, to the extent the artist is given the word that enables darning the underground with the practice of natural fields of professional performance, he/she will operate in the continuous circuit between an inside and an outside market, between work and pleasure, between playing and doing, as signals Tamara Alves' pointillism of experimentations. We conclude, provisionally, that the boundaries between the time of fruition of life and that related to work are increasingly narrowed in the scope of professional practices considered creative, thus setting up new branches and modulations of what is known as work and profession.
\end{abstract}

Keywords: urban art; professional experimentation; overlapping circuits; creativity. 


\section{Rastros de um percurso metodológico}

Estive em Lisboa acompanhando intervenções de artistas urbanos ${ }^{1}$ durante o um intervalo de tempo mais restrito. Desde o início da investigação, e talvez tenham sido estas as únicas delimitações prévias da pesquisa, decidi estudar intervenções não permitidas pelo poder público e mais relacionadas ao muralismo e ao graffiti, qual seja, a arte urbana. $O$ fato de dispor, inicialmente, de apenas um ano para a pesquisa de campo, certamente dificultaria o contato com os writers $^{3}$ e embaraçaria, sobremaneira, o acesso aos sujeitos que espalhavam suas tags ${ }^{4}$ pela cidade de Lisboa, tanto por serem numerosos como por se protegerem com as máscaras da ilegalidade. O contorno da investigação se voltou para aqueles que, mesmo sob as tintas da ilegalidade, ${ }^{5}$ desenvolviam um tipo de intervenção com uma aproximação mais nítida com as artes de rua ou muralismo.

1 Utilizo a categoria arte urbana, ou artes de rua, como expressão que engloba tipos diversos de linguagem e intervenção artística, tendo o urbano como cenário e/ou como suporte. De acordo com Campos (2010), o graffiti é um dos elementos emblemáticos da cultura visual contemporânea. Waclawek (2008, p. 121) indica, também, ser o graffiti uma forma de inserção transgressiva nas paisagens socioculturais das cidades, sendo marcado por sua natureza ilegal e pelo vetor da rebeldia. No âmbito da arte urbana, além do graffiti, as pinturas de muros, também designadas de muralismo, o estêncil, técnica de pintura por meio de elementos vazados, a colagem ou lambe, os stickers, dentre outros, inserem-se dentro do mesmo universo semântico. Esse resumido quadro expressa a natureza distinta e imprecisa que marca o empenho de totalização das experiências de intervenção urbana tão somente no corpo de uma categoria, sendo mais comum o uso do termo artes de rua, ou arte urbana, para designar as referidas intervenções.

2 Bolsa da Capes para Pós-Doutorado em Antropologia, no Instituto de Ciências Sociais (ICS) da Universidade de Lisboa, sob supervisão do professor José Machado Pais, durante o ano de 2103.

3 No corpo deste artigo, identificarei os atores que atuam nesse múltiplo terreno sob a denominação de writers, como aqueles que deixam seus escritos, suas marcas na cidade.

4 O termo tag refere-se à assinatura comumente utilizada para nominar os graffiti ilegais. Vale ressaltar que, em Lisboa, o termo "graffiti' engloba tanto os sujeitos que utilizam a expressão mural de desenhos com cores e consecução mais demorada e detalhada quanto aqueles que, no Brasil, são comumente designados de pichadores.

5 Vale ressaltar que no dia 23 de agosto de 2013 foi promulgada em Lisboa a lei ${ }^{\circ}$ 61/2013(Portugal, 2013), que “....] estabelece o regime aplicável aos grafitos, afixações, picotagem e outras formas de alteração, ainda que temporária, das caraterísticas originais de superfícies exteriores de edifícios, pavimentos, passeios, muros e outras infraestruturas, bem como de superfícies interiores e ou exteriores de material circulante de passageiros ou de mercadorias", prevendo coimas para os infratores que podem chegar a 25 mil euros. 
Após a configuração do escopo da investigação, havia um significativo desafio a ser transposto, de natureza tanto operacional como empírica. Como era desconhecida entre os sujeitos que faziam intervenções nas ruas de Lisboa e pouco contava com a ajuda de mediadores locais, decidi criar uma espécie de blog-diário de campo, denominado AntropologizzZando (Diógenes, 2013b). O blog tanto conferiu visibilidade ao intento da pesquisa, acelerou seu ritmo, como catalisou a participação de outros potenciais narradores ainda não vinculados ou conhecedores da proposta etnográfica em curso. Tal qual consignei em um artigo que descreve com mais pormenores esse percurso metodológico,

[...] imaginei que, em se tratando de uma pesquisa in between, o blog tanto propiciaria a partilha célere de anotações quanto poderia atuar, também, como "dobra" etnográfica, anexando planos distintos e, comumente, fragmentados de observação. (Diógenes, 2015, p. 540).

Foi nesse caminhar que encontrei Tamara Alves, ${ }^{6}$ ao passar na Calçada da Glória em um final de março de 2013 , durante o processo de produção de um mural ${ }^{7}$ feito em homenagem a Almada Negreiros. Já havia decido que, ao contrário de outras pesquisas balizadas por um critério mais rigoroso de delimitação do espaço geográfico de observação, nessa circunstância, iria tomar a caminhada

6 "Nascida em 1983, em Portimão, Tamara Aleixo Alves licenciou-se em Artes Plásticas na ESAD (Escola Superior de Artes e Design) nas Caldas da Rainha em 2006, e fez o Mestrado em Práticas Artísticas Contemporâneas na Faculdade de Belas Artes do Porto em 2008. O período em que viveu em Birmingham, Inglaterra, foi decisivo para a definição de uma linguagem plástica inspirada na vivência urbana. Utilizando suportes com características multifacetadas - da pintura, à ilustração, da instalação à performance; Tamara interessa-se por uma arte 'contextual', que se insere no mundo, abandonando lugares comuns como museus ou galerias, para apresentar as suas obras na rua ou em espaços públicos" (Diógenes, 2013d). Vale ressaltar que além da singularidade relativa à multiplicidade de fazeres, da diversidade de profissões desenvolvidas por Tamara, de seu trânsito entre as artes de ruas e as "belas artes", ela é identificada como sendo uma das poucas "meninas" que figuram no cenário das artes urbanas em Lisboa, tal qual aponta uma recente publicação da revista Time Out: "Vhils, Bordalo II, Aka Corleone, \pm MaisMenos \pm , Tamara Alves ou Mário Belém são alguns dos nomes mais sonantes neste roteiro de arte urbana em Lisboa. A eles juntam-se artistas de todo o mundo, que escolhem Lisboa para servir de tela aos mais variados estilos e mensagens" (Real; Lobo, 2019).

7 Tratava-se da produção de um mural, inaugurado no dia 7 de abril, na Calçada da Glória, com a exposição coletiva de arte urbana em homenagem a Almada Negreiros denominada Almada por se7e. Para saber mais sobre a exposição, ver Câmara Municipal de Lisboa (2013). 
na referida zona histórica ${ }^{8}$ e os encontros com as artes e artistas de rua como critério de seleção dos narradores e marcação da experiência etnográfica. Tal qual pontua Agier (2011), o campo relativo ao trabalho etnográfico é constituído pelas relações que podem ser possíveis, relações interpessoais movimentadas pelo próprio investigador. Minhas caminhadas diárias na referida zona histórica de Lisboa possibilitaram-me divisar "uma curiosa tela pictórica com reiteradas mutações" (Diógenes, 2015, p. 539), assim como a profusão de autores que ora assinavam, ora não, as referidas telas. Isso exigia, quando se tratava da ocultação da autoria, o desenvolvimento de um tipo de olhar etnográfico capaz de discernir nuances entre estilos, no uso das cores, na recorrência de elementos visuais, nos planos de composição, formando uma pluralidade de distinções estéticas.

Não apenas acompanhava as mudanças que ocorriam cotidianamente como mirava possíveis linhas de continuidade entre o plano presencial das intervenções nas paredes e no ciberespaço. ${ }^{9} \mathrm{~A}$ investigação realizada entre espaços materiais e digitais, operando por meio de um blog-diário de campo, produziu uma espécie de pesquisa em ato, sendo ela continuamente escrita, rasurada, apagada, complementada conforme a malha de conexões e participações que se efetuavam no decurso das publicações e anotações. Ao invés de seguir uma via da lógica ininterrupta do tempo, nesse entre espaços pude observar que o pesquisador se desloca por meio das próprias alterações que a investigação promove. Com a finalidade de situar a peculiaridade dessa experiência etnográfica, em um dos primeiros diários publicados no AntropologizzZando, destaquei:

Efetua-se uma etnografia a atravessada por fluxos, como se ela mesma fosse uma rede de olhares difusos sobre um mesmo ponto. Ao invés de seguir uma via da lógica ininterrupta do tempo, da sequência linear de lugares e etapas a serem cumpridas, o pesquisador desloca-se por meio das próprias alterações que a investigação promove. (Diógenes, 2013c).

8 A área de percurso quase diário da pesquisadora iniciava-se no Largo do Rato, passando pela Rua da Escola Politécnica, chegando ao Chiado, atingindo o Rossio, descendo até o Cais do Sodré e retornando por toda extensão da Avenida da Liberdade.

9 O ciberespaço se distingue como um regime digital, tal qual ressalta Christine Hine (2010, p. 9), que não se diferencia das experiências de percepção e construção da cultura efetuadas nas relações face to face. 
Em consonância com Velho (2009, p. 14), esse campo de investigação palmilha o tradicional contato da pesquisa face to face às mais variadas estratégias de pesquisa como a virtual, possibilitada pela informática, computadores, e-mails, etc. Desse modo, a noção de cidade, como lugar estabelecido de forma cingida nas cartas geográficas, também acaba por se deslocar por panoramas não materiais, formando híbridos entre tecnologias digitais e estruturas concretas. Um campo movente, cujo lugar se opera segundo a lógica do movimento dos narradores entre espaços e os meios por eles utilizados de partilha e de comunicação de imagens e palavras. ${ }^{10}$

Além do desafio de uma pesquisa entre ambientes, decidi observar cada narrador em seu contexto próprio, não comparativo, destacando singularidades na produção e inserção de suas artes nas ruas e na construção de suas trajetórias. Passei não apenas a conversar com os artistas, a acompanhar suas intervenções, como a participar de outras atividades e a partilhar outras experiências. No caso de Tamara, estive em momentos em que a mesma atuou como DJ, expôs suas obras, e em suas deambulações nas ruas de Lisboa no curso de caminhos costumeiros. $^{11}$

Vale ressaltar que escolher apenas uma voz, um sujeito único, não significa "escamotear o peso e a importância da sociedade, que de alguma forma, produz os indivíduos", como bem destaca Velho (1986, p. 56). Ao contrário, trata-se de entender melhor a gramática social que se opera em nível biográfico. Que signos dessa gramática, no caso de Tamara, expressam os circuitos entre arte e rua que perfazem a trajetória da tão destacada writer portuguesa?

No traçar dos primeiros passos da observação etnográfica, durante o intervalo de um mês, efetuei um tipo de estudo exploratório na zona demarcada. Identifiquei e anotei os artistas "ilegais" mais recorrentes e a localização de

10 Já havia trilhado a experiência da observação etnográfica no ambiente da internet ao pesquisar sobre juventude e torcidas organizadas de futebol, o que facilitou tanto a criação do blog como o processo de produção de diários de campo relativos à observação em meio virtual. Ver Diógenes (2013a).

11 Tal que ressaltam Eckert e Rocha (2013, p. 132), "no consentimento da experiência partilhada, o tempo de convivência é tanto mais denso tanto quanto densa se torna a demanda de observar situações vividas e de escutar suas falas". Considero que o tempo em que estive ao lado de Tamara, em suas atividades cotidianas, tenha se revelado mais rico de descobertas e de aproximações do que mesmo as situações de conversas ou entrevistas mais dirigidas ao esforço da pesquisa. 
suas intervenções. Concomitantemente, realizei, nos programas de buscas nas redes sociais digitais, informações diversas sobre os atores identificados e a singularidade de suas trajetórias. Tamara Alves, antes do mencionado encontro na Calçada da Glória, já havia me chamado atenção, não apenas por ser um nome de destaque nas buscas sobre arte urbana em Lisboa, não somente por ser umas das únicas mulheres ${ }^{12}$ destacadas na cena, mas por suas características emblemáticas. A artista personifica aquilo que Almeida e Pais (2012, p. 8, 13) identificam como uma "nova tribuna da imaginação", "um desafiador diagrama da criatividade contemporânea". Tamara se autoidentifica como tatuadora, DJ, designer gráfica, performer, artista plástica, sendo inspirada pela poesia, literatura, música e apreciações das artes que povoam as ruas.

Observa-se que as artes de Tamara atuam na condição de malha (Ingold, 2012), escapando de fronteiras predefinidas, de pontos de ação prefixados, vazando em distintas direções e superfícies. Ora tatua na pele, ora pinta na parede, ora usa os pincéis sobre a tela, ora utiliza sua agilidade nos desenhos digitais. Interessa-nos, assim, nos limites desse artigo, perceber como essas interfaces de fazeres e saberes efetuadas por Tamara Alves geram um modo peculiar de produção de bens artísticos e um singular percurso de profissionalização.

\section{Linguagens estéticas de Tamara Alves}

Para Tamara, arte e cidade são dimensões que se estreitam e se retroalimentam. As primeiras observações registradas no blog AntropologizzZando sobre

12 Mesmo considerando a importância do destaque de uma writer portuguesa em um cenário demarcado por figurações dominantes do gênero masculino e a emergência daquilo que Butler (2014, p. 39) denominou de "subversão da identidade" (com o efeito de práticas discursivas; no caso de Tamara, de práticas artísticas); e ainda o fato da mesma transpor, com a visibilidade de sua inserção nas ruas gramáticas substancializantes e hieraraquizantes de gênero (Butler, 2014, p. 47), prefiro, neste momento, não aprofundar o campo das discussões da categoria gênero. O foco de reflexão deste artigo, por meio do caso exemplar de Tamara, volta-se para rotas, conexões e temporalidades múltiplas que vão se desenhando e transmudando o campo das profissionalizações e intervenções desenvolvidas pela artista. Ainda dialogando com Butler, observo que a proeminência de uma artista diante de um cenário marcadamente masculino, tal qual sublinhado, põe em xeque o "discurso cultural hegemônico", referido pela autora, dos homens portadores de uma "pessoalidade universal" (Butler, 2014, p. 28). 
Tamara já indicavam sua natureza multifacetária, sua despadronização dos preceitos canônicos das artes plásticas, sua inserção borrada nas ruas, instaurando uma espécie de circuito contínuo entre arte e cidade.

Para a street artist, a arte não existe abstraída da cidade, nem o artista de rua utiliza a cidade apenas como suporte de suas obras. Nesse sentido a cidade, também, é arte e as inscrições do autor das obras ampliam a potência dessa linguagem. Rompe-se assim a distância espectador-obra-de-arte, artista e não-artista, transpondo a cidade para o domínio dilatado das experimentações. Como se poderá apreciar a seguir, Tamara produz novas ondulações nos padronizados vaivéns urbanos. (Diógenes, 2013e).

Em uma trajetória de múltiplas experimentações, Tamara parece afastar-se da tradicional ideia de "carreira linear", balizada por saberes e fazeres de natureza "cumulativa" e "unidirecional", comumente visualizada na forma de ascendência (Eugênio, 2012, p. 232).

[...] a carreira pensada como totalidade cede lugar a uma autonomia do fragmento: a cada projeto é possível mudar de posição e de atividade e "aprender fazendo", incorporando novas habilidades. Ninguém é mais uma coisa só, decreta o "descolado" colunista Tom Leão $0^{13} \mathrm{em}$ reportagem sobre a slash generation.

As variadas atividades de Tamara, ao invés de colidirem entre si, retroalimentam-se, potencializam vasos comunicantes de criação e acabam sustentando a ideia de que ninguém é mais uma coisa só. Nas intervenções de rua da artista, destacam-se, de modo geral, corpos humanos fundidos à forma animal, desenhos que escapam de suas molduras, tintas que escorrem e apontam a plasticidade do fazer artístico. Trata-se de conexões que se realizam entre atividades marcadas pela vontade de experimentar, de imprimir sentidos plurais e diversos ao que se faz: "Quanto mais coisas se fizer, melhor. [...]

13 Ver Leão (2010). 
Então, pronto, tentar fazer com que o meu trabalho faça sentido para mim e passe a minha mensagem. ${ }^{14}$

A construção das obras parece coincidir com os percursos marcados pela versatilidade das práticas artísticas da writer Tamara Alves. A artista enfatiza, frequentemente, que a sua formação nas artes visuais ocorreu, de modo geral, entre experiências combinadas: música, literatura, artes plásticas, etc.

Então, eu, quando comecei... na faculdade, quando estava a tirar o curso, a minha maior inspiração para os trabalhos que fazia era a poesia... a literatura e a poesia beat generation e muito, tipo, Patti Smith. Todas as letras e a música sempre foram as minhas maiores inspirações para saber o que é que eu ia pintar, o que é que eu ia retratar. Entretanto, tinha amigos meus que eram DJs, e... a peça, o vinil, antes mesmo de sequer pensar em pôr música, o vinil, já eu trabalhava. Já era uma coisa que... até que começou a surgir [a possibilidade de pôr música], e as pessoas começavam a gostar dos meus alinhamentos, das minhas escolhas, e... isso foi acontecendo. No Porto, tinha uma dupla com uma VJ - éramos três meninas. Depois vim para Lisboa e isso parou um bocado, porque, às tantas, já estava um bocado... já ouvia música, já só a pensar onde é que ia colocá-la, em vez de ouvir música pelo prazer de ouvir música... Então, decidi parar. Durante dois anos, não... nem pensei nisso. Depois conheci mais pessoal que [dizia] “ah, por que é que não voltas a tocar?". Entretanto, fizemos um regresso e ainda fomos tocar ao Ritz... Depois comecei, como essas minhas amigas eram do Porto, comecei a ter... a arranjar outro tipo de duplas, para não tocar sozinha. Porque é chato quando estás ali quatro horas sozinha, só ali... estás a trabalhar onde os outros se divertem... [ri]. Mas também era um prazer, e, como tinha boa recepção, acabei por começar a fazer as minhas seleções sozinha.

Algumas vezes, fica difícil definir fronteiras (é música, é arte de rua, é tatuagem, são artes plásticas?), já que as experiências artísticas de Tamara parecem ter

14 Entrevista realizada com a artista Tamara Alves na cidade de Lisboa, por Glória Diógenes e Vitor Sérgio Ferreira, em novembro de 2013. Todas as demais citações de Tamara que não tenham outra fonte identificada provêm dessa mesma entrevista. 
como móvel a lógica das sensações (Deleuze, 2011) ${ }^{15}$ de campos misturados: ${ }^{16}$ "Todas as letras e a música sempre foram as minhas maiores inspirações para saber o que é que eu ia pintar, o que é que eu ia retratar." Os circuitos sobrepostos de percepções no curso das experiências artísticas expressam-se também por meio da linguagem estética das obras de Tamara, seja nas paredes, na tela ou nas peles em que tatua:

Quando eu estou a pintar... quando eu estava a pintar a parede... mas eu, normalmente, eu pego em tinta, pinto, não estou preocupada com o que vai sair dali, depois é que faço o desenho, em cima. E toda a tinta que está por baixo é um acidente. E o jogo que faz com a imagem não é controlado por mim. E todo o dripping da tinta, a escorrer, e o salpico...

A trajetória de Tamara ${ }^{17}$ se inicia, ainda quando miúda, misturando latas, sujando o quarto e a cara toda. ${ }^{18} \mathrm{O}$ vetor sujidade, tantas vezes enfatizado pela artista ao longo de nossos encontros, vai compondo e dando significado à sua locução estética: ${ }^{19}$ e toda a tinta que está por baixo é um acidente. A arte, autoidentificada como subversiva pela writer, tal qual uma intervenção realizada pela artista em Alcobaça, acopla-se ao papel em branco e ao sujo da parede, promovendo o inesperado, o acidental, como domínio e potência da arte.

O mais interessante na arte urbana, faço um trabalho mais ilustrativo mas no fundo tem essa coisa de que eu faço um convite, é subversivo. Eu fiz uma instalação

15 No livro Francis Bacon: a lógica das sensações, Deleuze (2011, p. 25) sugere que "a sensação é o nome que se atribui ao fenómeno de contracção e de conservação de vibrações que estão aí, independente de qualquer sujeito. O devir-sujeito dá-se por vias diversas e uma delas é a sensação."

16 Alusão à obra de Michel Serres (2001, p. 23), Os cinco sentidos: "Ninguém pode pensar a mudança, a não ser sobre misturas: quando se tenta pensar o simples, só se chega a milagres, saltos, mutações, ressureições, até à transubstanciação. Eis a mudança em títulos, em ligas, em tecidos e mapas, eis a mudança por desenhos e reações, chamalote por chamalote, mestiçagem."

17 Tamara Alves cresceu no Algarve, fez o curso de artes plásticas nas Caldas da Rainha e o mestrado em práticas artísticas contemporâneas na Universidade do Porto.

18 Ver no documentário produzido pela autora, Rastos da arte urbana em Lisboa (2014), a fala de Tamara Alves.

19 Assim como Jacques Rancière (2009, p. 12-13), entendo que "a estética não designa a ciência ou a disciplina que se ocupa da arte. Estética designa um modo de pensamento que se desenvolve sobre as coisas da arte e que procura dizer em que elas consistem enquanto coisas do pensamento." 
num festival em Alcobaça, na única parede que tinha sentido para mim fazer, era a parede do mosteiro. E aquilo foi supercomplicado, tive que colar dez metros de papel, todo cortado. O que fiz foi um estêncil e colei com Bostik para não danificar a parede, porque aquilo é um patrimônio, e durante uma semana teve lá o meu mural. Eu não pintei, o papel era basicamente branco e a parede estava suja, e os desenhos apareciam da sujidade da parede, só nos recortes. E ao mesmo tempo que aquilo é um estêncil que já está feito, já está pronto, basta chegar lá alguém para pintar, mas não foi ninguém. Isso era só um convite. Ninguém fez, mas podiam ter feito e eu não tinha nada a ver com isso. (Diógenes, 2013e).

O estêncil que se conecta às sujidades da parede poderia ter sido atravessado, crossado, ${ }^{20}$ como sugere o convite silencioso da autora, mas não foi ninguém: ninguém fez, mas podiam ter feito e eu não tinha nada a ver com isso. Por se tratar de uma obra aberta, nas palavras de Tamara, a possível interferência do outro sinaliza, virtualmente, a natureza acidental da intervenção.

Por tal razão, Tamara enfatiza que, quando pinta na rua, já espera que ela seja tagada, ${ }^{21}$ que o artista é qualquer um dos mortais, e que, uma vez realizada a obra, ela já não pertence ao artista, e sim à rua:

O primeiro contexto da rua em si é tudo. Acho que o fato, o abandono da peça na rua é doloroso, mas faz parte. É preciso haver uma espécie de afastamento, [...] a partir do momento em que tá feito deixa de ser meu e acaba por ser dos outros, e vive com o tempo, e desgasta-se com a passagem, e num [sic] escolhe, é eclético, não escolhe público. O local influencia, como é óbvio, mas o desgaste é a intervenção dos outros artistas em cima, isso faz tudo parte. Isso eu acho, a obra não tá finalizada, não tá enquadrada pra já, não é tela, nem um retângulo acadêmico, é exterior. ${ }^{22}$

Observa-se, nos traços da autora, a necessidade de se ultrapassar retângulos acadêmicos, de acoplar, combinar, fundir, conectar domínios comumente separados.

20 Pintar ou riscar por cima da obra de outro writer.

21 A artista se refere à possível assinatura, ou tags, como costuma marcar a ação dos graffiters ilegais.

22 Gravação realizada com a artista Tamara Alves para produção do referido documentário Rastos da arte urbana em Lisboa (2014). 
Talvez por isso, quase toda a obra de Tamara aponta para uma animalidade, sendo essa expressão "não humana" mais uma esfera de conexão, uma espécie de fusão gente-bicho.

Eu gosto de saber que o meu trabalho transmite a força primitiva. Sou muita intensa. $\mathrm{O}$ fato de poder ser visto como masculino pra mim é ótimo, não estou ali a tentar representar um gênero. E mesmo às vezes quando pinto tanto o animal. Quando as pessoas veem o retrato têm dificuldade em se identificar porque há sempre uma figura que não é a deles. E eu pintava muito mais retrato e misturava amigos com pessoas que eu idolatrava, desde músicos, artistas a figuras. Mas teve um ponto que eu percebi: "ok, a pessoa vê, gosta, se calhar percebe, mas não se identifica". Eu comecei a usar mais a figura do animal por pensar - com um animal, qualquer pessoa consegue se identificar. Eu depois eu comecei a retirar a expressão, os olhos, porque aí retira um bocado do gênero, de ser feminino, de ser masculino. (Diógenes, 2015c).

No diário de campo publicado no AntropologizZZando (Diógenes, 2013d), no dia 25 de abril de 2013, intitulado "A animalidade no ciberespaço", ressalto as transfigurações que permeiam a obra de Tamara, assim como as misturas e conexões que singularizam sua linguagem pictórica.

A obra de Tamara nos convoca a transpor compartimentações, dualidades, bifurcações. Razão e instinto, comumente, excludentes nas obras acadêmicas, cultura e corpo assumem nas transfigurações de Tamara uma tensão, um encontro afora do organismo. Criando assim, com suas artes uma história singular, um devir animal, uma experimentação, uma transfiguração. E percebo que essa profusão de sensações, também, passa a povoar o ciberespaço, como ressalta Suely Rolnik:23 Embarcamos numa acelerada transfiguração, para a qual contribui especialmente a indústria da informação e da transformação digital. Imagens, sons e dados de toda espécie navegam pelas artérias eletrônicas, cada vez mais rápida e instantaneamente, fazendo com que cada indivíduo seja habitado simultaneamente por fluxos do planeta inteiro.

23 Ver Rolnik (1995). 
O caráter efêmero e inconcluso das artes de Tamara, o não "enquadramento", o "abandono da peça", o "afastamento", a projeção do "desgaste", o borrar das fronteiras e o destaque à sujidade promovem zonas de possibilidades de ações justapostas dentro do circuito indiscernível entre "obra finalizada" e "obra aberta", entre "afastamento" do autor e propriedade da obra: ${ }^{24}$ " [...] a partir do momento em que tá feito deixa de ser meu e acaba por ser dos outros". A caracterização da construção da linha artística de Tamara aponta uma diáspora da artista no que tange às esferas da representação. A combinação de múltiplas experiências no fazer arte aponta para uma certa revolução estética aludida por Rancière (2009, p. 25), no que concerne à "abolição de um conjunto ordenado de relações entre o visível e o dizível, o saber e a ação, a atividade e a passividade". Observa-se, como veremos a seguir, que os circuitos de experiências variadas operam-se, também, na formação e prática profissional da artista, evidenciando ainda mais vestígios da referida revolução. Está tudo ligado. É a frase, é a cor, é o traço, é a música: “...] Há certo tipo de músicas que eu tenho de ouvir. Agora tenho de ouvir isto, para pintar isto, para sentir!... porque é o ritmo, ou é o grito, ou é a batida... que é para me fazer sentir aquilo que eu quero fazer."

Há um fio que tudo embaralha e unifica: experimentar, criar, identificar um sentido para o que se faz, sorver do prazer em executar cada tarefa constituem, nessa paisagem discursiva, aquilo que Almeida $(2012$, p. 26$)$ denomina de "redefinições contemporâneas da profissionalização".

\section{Entre legal e ilegal: trabalho e prazer}

A obra aberta de Tamara Alves tenta traspassar não apenas a ideia de autoria, tão bem sintetizada no título de uma intervenção por ela realizada - o artista é qualquer um dos mortais ${ }^{25}-$, mas também usuais fronteiras que conformam as práticas urbanas consideradas legais e ilegais. Algumas vezes, ressalta Tamara,

24 Um dos artistas pesquisados durante 2013, Hazul Luzah, observou que a obra localizada na parede da Boa Vista havia sido utilizada por um vídeo promocional da McDonald's. Essa polêmica foi noticiada no jornal O Público com a seguinte enquete: "A arte urbana tem direito de autor?" (Henriques, 2014).

25 Intervenção organizada pela artista em Caldas da Rainha, em que ela fazia desenhos e trocava outros com sujeitos diversos, como crianças, bêbados, artistas, transeuntes, entre outros. 
essas instâncias se complementam: quem faz legal se aperfeiçoa, é pago, e o dinheiro pode, assim, dar suporte às práticas ilegais. ${ }^{26}$

Um purista do graffiti, o graffiti em si, por mais que forme o legal, deve continuar a ser ilegal. A melhor parte é termos paredes legais. Porque, enquanto é ilegal, tens que trabalhar mais rápido, e às vezes o trabalho pode não ficar como nós queremos. Melhor parte de ter uma parede legal é que lá podemos demorar uma tarde inteira, aperfeiçoar a técnica, aperfeiçoar o traço. A melhor parte das paredes legais é que se pagam para trabalhar lá, é que esse dinheiro pode servir para trabalho ilegal. O material é caro. E fazer graffiti é caro, é caro alimentar este tipo de arte, não é qualquer um que pode ter cem latas em casa. Acho que a maior parte do trabalho legal é podermos, sim, aperfeiçoar a técnica e não estar preocupado com a polícia, ou com pagar multas, ou coisas do gênero. O ilegal é a essência do graffiti. Ele é uma arte marginal.

Aperfeiçoa-se a arte no trabalho legal para que se possa experimentar a agilidade demandada no âmbito das intervenções ilegais: uma e outra se aproximam e, de certo modo, se rematam. Na discussão efetuada por José Simões (2012, p. 190) sobre "Viver (d)o hip-hop: entre o amadorismo e a profissionalização", o autor assinala:

Assim, não é apenas o facto de os circuitos mainstream serem compatíveis com os circuitos undergrounds que merece ser notado, mas igualmente o facto de os mesmos artistas poderem conciliar ambas as opções na sua trajectória, mesmo sabendo que representam realidades diversas, com uma importância simbólica diferenciada.

26 Embora a discussão acerca dos múltiplos fazeres de Tamara Alves, por vezes, assuma vizinhança com os processos de comercialização de suas obras em galerias, com sua atuação no mercado na qualidade de designer gráfica, tatuadora, no ato de transformar certos artefatos e ações em arte, prefiro não adentrar o instigante campo de discussão dos processos de artificação que mobiliza o cenário das artes contemporâneas. Observa-se que a trajetória artística de Tamara aponta facetas um pouco diferenciadas do que Shapiro e Heinich (2013, p. 23) identificam nos processos de artificação, tendo em vista que a própria sustentabilidade, estetização, individualização da produção artística da writer portuguesa perfaz uma via diferenciada do vetor que segue a linha vandalismo-arte, criando domínios conectados e fluxos contínuos entre rua, galerias e mercado. As obras e feitos de Tamara Alves apontam assim, com mais nitidez, a permeabilidade que assumem as fronteiras artísticas nas artes contemporâneas. 
É, de certo modo, o vaivém desse fluxo dos bens e o percurso efetuado pela própria artista (Kopytoff, 2008) que acabam por produzir torneios de valor, fazendo com que uma produção underground assuma, na sua biografia, feições de não mercadoria e, ao mesmo tempo, circule e ganhe expressão no mundo mais ampliado dos bens. ${ }^{27}$

Os vários encontros com Tamara e a visita a duas de suas exposições (inclusive um fragmento da publicação do blog AntropologizZZando integra o texto de apresentação ${ }^{28}$ da primeira mostra) foram sinalizando a singularidade de uma artista que, embora identificada com o mainstream, nas atividades de designer gráfica, nas produções relativas às escolas de arte e galerias, na sua relação próxima com a Galeria de Arte Urbana (GAU), na sua incursão acadêmica, agencia, também, aproximações com a dinâmica e a estética das artes de rua.

Sendo assim, ao invés do usual circuito efetuado por alguns writers que têm seu rito de passagem das ruas para galerias e "paredes legais", Tamara efetua um fluxo "misturado", entre ruas e galerias, entre paredes legais e paredes ilegais, em tempo simultâneo. A perspectiva de ocupar os espaços legais para ter latas para o ilegal sugere o que Eugênio (2012, p. 243) considera "um elogio à mistura e à instabilidade, o prazer com a transformação constante do entorno e das atividades...". Nas ações efetuadas em esferas contíguas legal/ilegal, rua/galeria em constante transfiguração, a ordem é sempre experimentar:

[...] e eu experimentei tatuar nela. Depois eu experimentei em mim... pronto, aquelas brincadeiras. E... depois fui vendo vídeos, e vídeos e vídeos, depois houve um amigo meu, que também tatuava em casa, que apercebeu-se que eu, apesar

27 Refiro-me ao livro O mundo dos bens: por uma antropologia do consumo, de Mary Douglas e Baron Isherwood (2013).

28 Há, nos desenhos de Tamara, uma espécie de violação das convenções que padronizam e disciplinam gestos e comportamentos, uma deslocação entre permitido e proibido, legal e ilegal. A obra da referida artista é uma espécie de convocação corporal. É como se cada uma de suas ilustrações evidenciasse o corpo e a arte como dispositivos de passagem, válvulas comunicantes de instintos. Na exposição de Tamara, intitulada To the bone, ela utiliza a seguinte passagem de um texto do AntropologizzZando: "A artista esboça o que Deleuze e Guattari cognominaram de um corpo sem órgãos. Suas pinturas transpõem hierarquizações que fundam os organismos, elas quase sempre alteram a posição de um membro ou órgão do corpo, encontrando um modo de escorrer, como circuitos dentro-fora, fora-dentro. A obra de Tamara enuncia-se como extensivo panorama erótico do corpo contemporâneo, agenciando contínuos efeitos de dilatação dos limites corporais" (Diógenes, 2013d). 
das asneiras, tinha um traço fixe. ${ }^{29}$ Mas para mim é importante: mexes em tudo, experimentas, podes trabalhar com tudo aquilo que te apetece. E é isso que eu tenho de memória das Caldas: é experimentar, experimentar, experimentar. É pegar em portas, pegar em lixo... fazer qualquer coisa, desde que isso transmitisse a mensagem que nós queríamos transmitir... era isso que interessava.

Há ligaduras entre esferas contíguas de temporalidades, conexões entre pluralidades de experimentações sem linhas previamente demarcadas, criando-se e recriando-se, sucessivamente, fusões e diferenciações entre domínios aparentemente separados. Assim, ao invés de a artista, no caso de Tamara Alves, definir-se desde cedo por uma linha, um modo de atuar, ela traceja o percurso contrário: reproduz possibilidades para que vá sendo descoberto o lugar possível de definição e de percepção de sua obra:

Eu, nas Caldas [ESAD], fazia muitas coisas; [...] comecei a perceber que isso suscita confusão na cabeça das pessoas. As pessoas precisam de equilíbrio, precisam de uma linha para saber quem tu és... de coerência. Se foges a essa linha, as pessoas ficam confusas e não o que é que... quem és tu. É como os rótulos, toda a gente tem necessidade de colocar rótulos.

Ao contrário do que se poderia prever - a experimentação, o traço arriscado e acidental exercido nas ruas, e os contornos precisos e calculados se voltarem para os "juízos de gosto" ${ }^{30}$ das curadorias de artes plásticas -, para Tamara, tudo se confunde e se amalgama numa mesma linha de trabalho:

Sempre gostei de trabalhar muitas áreas e muitos estilos diferentes. Acho que... de início, para provar a mim própria que era capaz. [...] Então, à parte dessa confusão toda, eu acho que cheguei a um ponto que consegui definir o meu estilo dentro das várias áreas, e as pessoas olham para o meu trabalho e dizem "isto

29 "Fixe" é uma expressão comumente usada pelos portugueses que significa o que no Brasil se costuma designar como "nossa, que legal!", ou designa o "estar bem", ou o belo, o agradável.

30 Refiro-me à discussão de Giorgio Agamben (2012, p. 37) acerca do "homem do gosto e a dialética da dilaceração", em que o autor aponta a emergência da figura do homem do gosto, "que é dotado de uma particular faculdade, quase de um sexto sentido - como se começou a dizer então - que lhe permite colher o point de perfection que é característico de toda obra de arte". 
és tu!". Consegui. Então, isso é importante para os artistas. É definir uma linha de trabalho... coerente, e que te identifique. Ahhh... por isso... Isso é importante: a arte ser identificada sem assinatura! Significa que chegaste a um ponto em que... está, está lá, está bem! [VSF: E quem és tu, no meio disto? No meio dessas coisas todas que fazes?] Eu acho que consegui, dentro desse caos todo, consegui juntar... é que depois fez tudo sentido.

É no compasso da confusão que se condensam as multiplicidades, paisagem que bifurca as conexões das várias áreas em que a writer atua: essa é sua linha de trabalho, a fusão de vários diagramas de ação e criatividade. ${ }^{31}$ Por tal razão, por não ter sido escolhida a priori uma linha de ação, por ela ir sendo desenhada ao longo do processo, "é que [apenas] depois é que vai fazer todo o sentido".

Na cadência da confusão, a obra de Tamara Alves tateia e atua em busca de um traço fixe, da liberdade de trabalhar com tudo aquilo que te apetece, no ato de pegar em portas, pegar em lixo e traduzir apenas o que interessa ao autor transmitir. Por tais razões, Tamara avalia que esse modo singular de atuação profissional não pode ser considerado simplesmente sob o epíteto de trabalho, chegando a ser percebido como um luxo de quem gosta do que faz.

Eu normalmente digo que, quando gostamos do que fazemos, não trabalhamos um único dia da nossa vida. Isto é frase de alguém que eu agora não me lembro. Eu sinto que estou assim. Gosto daquilo que faço... às vezes mais, outras vezes menos... às vezes menos condicionada, ou mais condicionada... Mas gosto. Gosto da vida social. [...] Gosto de fazer uma pintura e ter feedback. Gosto de tocar e ter pessoas a dançar. Gosto de... gosto daquilo que faço. A partir do momento que deixar de gostar, acho que... há coisas que serão eliminadas, ou... Às vezes sinto que toco, se toco, sei lá, três vezes por semana, se começo a enjoar da música, paro. Faço uma pausa até voltar a gostar: "Ah, agora quero outra vez." Então,

31 Tim Ingold (2015, p. 309), no livro Estar vivo, no instigante diálogo com Paul Klee, aponta a perspectiva da criatividade esboçando-se afora da dimensão do produto do que se realizou, da obra final, qual seja retrospectivamente “[...] a partir de um resultado na forma de um objeto novo [...]". Por tal razão, empreendi ao lado de Tamara um olhar que mais se volta para a ideia de processo, já que a "obra convida o espectador a juntar-se ao artista como companheiro de viagem, a olhar com ele, enquanto desdobra-se no mundo [...]" (Ingold, 2015, p. 309, grifo do autor), do que me deter a olhar e tentar compreender a criatividade contida em suas obras. 
dou-me a esse luxo. Tenho... [VSF: É um luxo? O fato de fazeres as várias coisas ao mesmo tempo, para ti, é um luxo?] Sim. Para mim, é um luxo. São todas diferentes, mas todas tocam. E são coisas que eu gosto de fazer, por isso, não é de todo... não é de todo... Acho que, para mim, é positivo. [...] Porque eu acho que há muita gente que... que esqueceu-se daquilo que gostava de fazer, ou do que era $o$ seu emprego de sonho, ou... Porque estavam demasiado ocupados a trabalhar. E, a partir do momento que ficaram sem esse emprego, como não têm mais nada a perder, resolveram fazer aquilo que gostavam.

O luxo de fazer aquilo que se gosta produz a sensação de que não se trabalhe um único dia na vida. Emprego do sonho e prazer misturam-se de tal forma que o ato de realizar várias coisas ao mesmo tempo parece desconectar-se do ritmo do trabalho enfadonho, aquilo que Hannah Arendt (1987) identifica como fadigas e penas. Essa capacidade de abrigar o que pode ser considerado irrelevante $^{32}$ cria tanto um encantamento no panorama do que, comumente, se considera trabalho como configura singulares relações entre corpo e cidade, entre indivíduos insularizados e a dinâmica de ações colaborativas que também, cada vez mais, ganham novos matizes na contemporaneidade.

\section{Quando criar é acidente}

Tendo em vista o curso das experiências "misturadas" de Tamara Alves, observa-se que o que parece estar em jogo diz respeito a uma forma de atuação, de trocas e habilidades artísticas/profissionais que promovem aquilo que Appadurai (1996, p. 16) designa como pluralidade de mundos imaginados.

Imaginar e compartilhar tornam-se âmbitos combinados de dribles e táticas para que se possa transpor compartimentações e interditos que povoam as cidades e delimitam usuais fronteiras entre trabalho e não trabalho, entre obrigação e fruição. As ações relativas a compartilhar, trocar, misturar e imaginar passam também a borrar as fronteiras entre o que se identifica como atividade

32 Hannah Arendt (1987, p. 62), no livro A condição humana, assinala que, "embora a esfera pública possa ser grande, não pode ser encantadora precisamente porque é incapaz de abrigar o irrelevante". 
profissional ou mero ato de obtenção de prazer. Considerando o que diz Marcel Mauss (2008, p. 56) no "Ensaio sobre a dádiva", quando observa que o mercado é um fenômeno humano, que existe "antes da instituição dos mercadores e antes de sua principal invenção, a moeda”, pode-se atentar que a cultura da partilha e das experimentações, efetuadas por Tamara Alves e por muitos artistas e não artistas, não necessariamente se projeta dentro ou fora do mercado, constituindo um pontilhismo entre práticas underground e ações inseridas no mainstream.

Os âmbitos de trocas são tantas vezes descontínuos que aquilo que os sujeitos produzem, na dinâmica das experimentações ensejadas por Tamara Alves, algumas vezes se encontra dentro e fora do mercado, assumindo um status ambíguo como uma espécie de "mercado negro das singularizações" (Kopytoff, 2008, p. 113). Certamente, os painéis pintados pela artista nas ruas de Lisboa, na qualidade de obras singulares, encontram-se fora do mercado de bens artísticos, mas certamente conferem valor às suas obras expostas nas galerias. Isso possibilita pensar, como profere o citado autor, na produção de uma emblemática biografia dos bens. Curiosamente, o que vai sendo produzido nas ruas, no "mercado negro", se conecta às demais criações da artista: seja no âmbito da publicidade, na comercialização das suas obras de arte, seja nas suas atividades de tatuadora ou de DJ. As obras da imaginação (Appadurai, 1996), os percursos acidentais da produção, a imagem que se esboça fora do controle contêm estreita conexão com a biografia dos múltiplos bens (Douglas; Isherwood, 2013) produzidos pela artista.

O mencionado dripping da tinta a escorrer, o salpico, é que vai definir a forma final da obra. E esse exercício da imaginação tem ultrapassado as fronteiras da arte, como ressalta Appadurai (1996, p. 17-20): “a imaginação saiu do particular espaço expressivo da arte, mito e ritual para passar a fazer parte da atividade mental cotidiana da gente vulgar de muitas sociedades [...] sendo a imaginação hoje um palco para a ação e não apenas para a evasão". Por tal razão, as diluições de fronteiras entre "obras do trabalho" e "obras da imaginação" possibilitam também, e cada vez mais, se tomar a arte como parte próxima das atividades e experiências não apenas de artistas, como no caso de Tamara Alves, mas na dinâmica de outros atores sociais identificados como inventivos e criativos.

Retomando o diálogo com Simões (2012, p. 193), o autor observa que, nas estratégias de profissionalização do hip-hop, fica cada vez mais difícil se visualizarem as fronteiras entre o domínio “do tempo 'livre’ e um domínio caracterizado por actividades de obrigação". Observa-se que, em todas as narrativas aqui 
compartilhadas, Tamara em nenhum momento exclui a palavra trabalho. $\mathrm{O}$ fato de apreciar atuar em várias áreas e saber que isso suscita confusão na cabeça das pessoas não a impede de desdenhar rótulos, nem de prosseguir ensaiando. Não há bifurcações em suas decisões entre os atos de nomadizar por variadas áreas, de não ter definida uma fronteira e das suas possíveis inserções na atividade comercial, seja como tatuadora, como DJ, seja como designer gráfica ou na condição de artista plástica. Campos (2010, p. 120) também identifica essa mesma extensão de possibilidades dentro do universo do graffiti, projetando uma abertura gradual em vários níveis: "exposições em galerias de arte, venda de graffiti em tela e, ainda, a decoração de espaços (bares, lojas, espaços públicos etc.).

Vale salientar que a fixação avizinhada entre produzir e comercializar ocorre, revelada por vários artistas com os quais estive em contato durante os anos de 2013 e 2015, em Lisboa, no vocábulo brincar. As divisas entre o tempo da fruição da vida e o relativo ao domínio do trabalho cada vez mais se estreitam no âmbito das práticas e profissões consideradas criativas - aquilo que Pais (2012, p. 161), no diálogo com Schutz, vai denominar de "o mundo dos materiais lúdicos e dos pequenos brincadores", ao pesquisar o universo dos produtores de quadrinhos. A brincadeira surge como camarim de ensaio, ensejo para que 0 caos revele linhas legíveis nos esboços sucessivos do emprego dos sonhos.

\section{O pessoal fixe não morre: algumas linhas conclusivas}

Essa frase ilustra uma série de imagens criadas por Tamara Alves: "o pessoal fixe não morre". Isso significa dizer que, para a artista, o ato de criar, de transmudar as rotas lineares de aprendizagem e do exercício profissional acabam por "sufocar" a potencialidade criativa e inventiva que se aplica para "qualquer um dos mortais". Vale ressaltar: não se trata de identificar quem é artista ou quem não é artista, quem é criativo ou quem não é, quem se situa no underground ou no mainstream, e sim quem se habilita a criar e transfigurar cenas costumeiras, onde quer que esteja, do modo que seja. Tamara indica que toda gente tem seu lado criativo, e que basta ser criança para que isso aconteça.

Toda gente tem seu lado criativo, de qualquer forma, toda gente consegue fazer qualquer coisa. Tem gente que às vezes chega e diz: "Eu não sei desenhar." Então 
eu digo: "Se calhar sabes fazer um origami e, se o colares na rua, já é uma coisa diferente." Basta ser criança, nesse aspecto.

A brincadeira, ou o luxo de fazer várias coisas ao mesmo tempo, quase nunca é uma experiência solitária: ela evoca o prazer das confabulações em grupo, ativa a dinâmica dos jogos e o júbilo da festa. Tal qual sinaliza Huizinga (2001), o jogo é capaz, a qualquer momento, de absorver inteiramente o jogador, assim como o brincante. Vale ressaltar que o sentimento de se permitir ser criança, de experimentar ver o mundo de cabeça para baixo, já que a arte emerge no espaço aberto da não inscrição, possibilita fundar lugares em que novas formas podem nascer (Gil, 2005). É por isso, como continua José Gil (2005, p. 29), “que a arte é ao mesmo tempo jogo e mais do que um jogo: as formas visíveis e o seu movimento continuam a ser simulações da vida (e de suas inscrições) [...]". O sujeito brincante, movido por um tipo de jogo colaborativo, pode ser equiparado ao nômade, ao "desterritorializado", 33 já que parece estar sempre disposto a deslocar-se dos lugares costumeiros. Ferreira (2012, p. 85), ao analisar as artes de tatuar, também sinaliza a importância dos contextos de sociabilidades artísticas no processo de formação e que "raramente o jovem tem, a priori, como objetivo de vida, tornar-se tatuador. É quase sempre 'acidentalmente' que a tatuagem é encontrada como alternativa ocupacional viável".

Os acidentes, como também pontuou Tamara Alves, o risco, os desvios contribuem para que se intensifiquem novas modulações de processos de formação profissional e para a gradual redefinição dos significados da categoria trabalho. Como bem ressaltam Almeida e Pais (2012, p. 17), "nessa nova criatividade relacional, o que prevalece [...] é uma cooperação entre modos de pensar e fazer, é um jogo de astúcias e audácias que coloca em estado de sítio a normatização". Tamara condensa em sua trajetória exemplar, por meio das janelas abertas à criatividade, da natureza misturada das experimentações em campos diferenciados de atividade, traços que recorrentemente contornam as paisagens das profissões contemporâneas. E adverte a artista, acrescentando

33 Deleuze e Guattari (1997, p. 53, grifo dos autores) ressaltam que "se o nômade pode ser chamado de o desterritorializado por excelência, é justamente porque a reterritorialização não se faz depois como no migrante, nem em outra coisa como no sedentário [...] para o nômade, ao contrário, é a desterritorialização que constitui sua relação com a terra, por isso ele se reterritorializa na própria desterritorialização". 
mais um indicador à lógica das novas ocupações: brincar pode ser um jogo sério. Remata Tamara, "adoro quando alguém diz 'eu quero isto' e então transforma e aparece qualquer coisa nova e diferente".

Certamente, a brincadeira é o que possibilita o estar vivo (Ingold, 2015) do pessoal fixe no complexo mercado das profissões e no amplo leque de singularizações da criatividade e das artes nas paisagens contemporâneas. A brincadeira emerge nas falas e na trajetória de Tamara Alves como valiosa metáfora que parece condensar, a um só tempo, linhas descontínuas que se desenham dentro e fora do mercado, no circuito das práticas legais e ilegais, no status ambíguo e movediço que assumem suas obras e intervenções entre o cenário das artes, o terreno do mercado e das profissões e a paisagem das ruas.

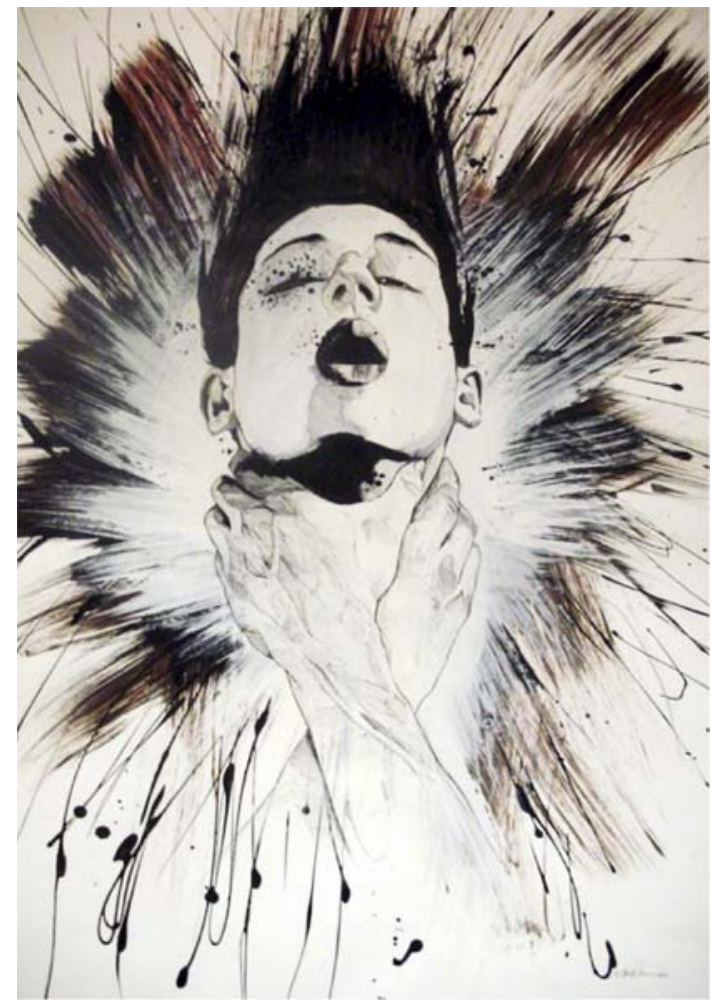

Figura 1. Mil corpos: intensidade e devir

(imagem cedida por Tamara Alves de seu acervo particular). 


\section{Referências}

AGAMBEN, G. O homem sem conteúdo. Belo Horizonte: Autêntica, 2012.

AGIER, M. Antropologia da cidade: lugares, situações, movimentos. São Paulo: Terceiro Nome, 2011.

ALMEIDA, M. I. M. de. Criatividade contemporânea e os redesenhos das relações entre autor e obra. In: ALMEIDA, M. I. M. de; PAIS, J. M. (org.). Criatividade, juventude e novos horizontes profissionais. Rio de Janeiro: Zahar, 2012. p. 21-55.

ALMEIDA, M. I. M. de; PAIS, J. M. Apresentação. In: ALMEIDA, M. I. M. de; PAIS, J. M. (org.). Criatividade, juventude e novos horizontes profissionais. Rio de Janeiro: Zahar, 2012. p. 7-20.

APPADURAI, A. Dimensões culturais da globalização. Lisboa: Editorial Teorema, 1996.

ARENDT, H. A condição humana. Rio de Janeiro: Forense Universitária, 1987.

BUTLER, J. Problemas de gênero. Rio de Janeiro: Civilização Brasileira, 2014.

CÂMARA MUNICIPAL DE LISBOA. Comemorações dos 120 anos do nascimento de Almada Negreiros. 5 abr. 2013. Disponível em: http://www.cm-lisboa.pt/noticias/ detalhe/article/comemoracoes-dos-120-anos-do-nascimento-de-almada-negreiros. Acesso em: 9 set. 2018.

CAMPOS, R. Porque pintamos a cidade?: uma abordagem etnográfica do graffiti urbano. Lisboa: Fim de Século, 2010.

DELEUZE, G. Francis Bacon: a lógica da sensação. Lisboa: Orfeu Negro, 2011.

DELEUZE, G.; GUATTARI, F. Mil platôs: capitalismo e esquizofrenia: vol. 5. São Paulo: Editora 34, 1997.

DIÓGENES, G. Signos urbanos juvenis: rotas da pichação no ciberespaço. Cadernos de Campo, v. 22, n. 22, p. 45-61, 2013a.

DIÓGENES, G. Página inicial. AntropologizZZando: arte urbana e graffiti em Lisboa, 2013b. Disponível em: http://antropologizzzando.blogspot.pt/. Acesso em: 22 ago. 2013.

DIÓGENES, G. O minimalismo intenso da arte de Tinta Crua. AntropologizzZando: arte urbana e graffiti em Lisboa, 23 mar. 2013c. Disponível em: https://antropologizzzando.blogspot.com/2013/03/o-minimalismo-intenso-da-arte-urbana-de.html. Acesso em: 22 ago. 2013.

DIÓGENES, G. Tamara Alves, animalidade no ciberespaço. AntropologizZZando: arte urbana e graffiti em Lisboa, 25 abr. 2013d. Disponível em: http://antropologizzzando. blogspot.com.br/2013/04/tamara-alves-animalidade-no-ciberespaco.html. Acesso em: 4 maio 2018. 
DIÓGENES, G. O mais comum dos mortais: corpos misturados na arte de Tamara Alves. AntropologizZZando: arte urbana e graffiti em Lisboa, 10 maio 2013e. Disponível em: http://antropologizzzando.blogspot.com.br/2013/05/o-mais-comum-dos-mortais-os-corpos.html. Acesso em: 2 set. 2018.

DIÓGENES, G. A arte urbana entre ambientes: "dobras" entre a cidade "material" e o ciberespaço. Etnográfica, v. 19, n. 3, p. 537-556, out. 2015.

DOUGLAS, M.; ISHERWOOD, B. O mundo dos bens: para uma antropologia do consumo. Rio de Janeiro: Ed. UFRJ, 2013.

ECKERT, C.; ROCHA, A. L. Etnografia da duração. Porto Alegre: Marcavisual, 2013.

EUGÊNIO, F. Criatividade situada, funcionamento consequente e orquestração do tempo nas práticas profissionais contemporâneas. In: ALMEIDA, M. I. M. de; PAIS, J. M. (org.). Criatividade, juventude enovos horizontes profissionais. Rio de Janeiro: Zahar, 2012. p. 210-258.

FERREIRA, V. Das belas-artes à arte de tatuar: dinâmicas recentes do mundo da tatuagem portuguesa. In: ALMEIDA, M. I. M. de; PAIS, J. M. (org.). Criatividade, juventude e novos horizontes profissionais. Rio de Janeiro: Zahar, 2012. p. 56-112.

GIL, J. A imagem-nua e as pequenas percepções: estética e metafenomenologia. Lisboa: Relógio d'Água, 2005.

HENRIQUES, A. M. McDonald's não pediu a Hazul para usar esta parede. $P 3,10 \mathrm{dez}$. 2014. Disponível em: http://p3.publico.pt/cultura/exposicoes/14934/mcdonald039snao-pediu-hazul-para-usar-esta-parede. Acesso em 5 out. 2018.

HINE, C. Virtual methods. New York: Berg, 2010.

HUIZINGA, J. Homo ludens. São Paulo: Perspectiva, 2001.

INGOLD, T. Trazendo as coisas de volta à vida: emaranhados criativos num mundo de materiais. Horizontes Antropológicos, Porto Alegre, ano 18, n. 37, p. 25-44, jan./jun. 2012.

INGOLD, T. Estar vivo: ensaios sobre movimento, conhecimento e descrição. Petrópolis: Vozes, 2015.

KOPYTOFF, I. A biografia cultural das coisas: a mercantilização como processo. In: APPADURAI, A. (org.). A vida social das coisas: as mercadorias sob uma perspectiva cultural. Rio de Janeiro: EdUFF, 2008. p. 89-124.

LEÃO, T. Documentário retrata os representantes cariocas da Slash Generation. O Globo, Rio de Janeiro, 9 set. 2010. Segundo Caderno, p. 3.

MAUSS, M. Ensaio sobre a dádiva. Lisboa: Edições 70, 2008.

PAIS, J. M. O mundo dos quadrinhos: o agir da obliquidade. In: ALMEIDA, M. I. M. de; PAIS, J. M. (org.). Criatividade, juventude e novos horizontes profissionais. Rio de Janeiro: Zahar, 2012. p. 143-185. 
PORTUGAL. Lei 61/2013, de 23 de Agosto. Estabelece o regime aplicável aos grafitos, afixações, picotagem e outras formas de alteração, ainda que temporária, das caraterísticas originais de superfícies exteriores de edifícios, pavimentos, passeios, muros e outras infraestruturas, bem como de superfícies interiores e ou exteriores de material circulante de passageiros ou de mercadorias. Lisboa, 23 ago. 2013. Disponível em: https://dre.tretas.org/dre/311214/lei-61-2013-de-23-de-agosto. Acesso em: 20 out. 2018.

RANCIÈRE, J. O inconsciente estético. São Paulo: Editora 34, 2009.

RASTOS da arte urbana em Lisboa. Idealização e produção: Glória Diógenes. Direção geral e roteiro: Glória Diógenes; Davi Diógenes de Carvalho. Fortaleza, 2014. 33min. Disponível em: https://vimeo.com/116549650. Acesso em: 18 set. 2018.

REAL, F. D.; LOBO, R. L. Siga este roteiro de arte urbana em Lisboa. Time Out, jan. 2019. Disponível em: https://www.timeout.pt/lisboa/pt/coisas-para-fazer/roteiro-da-arte-urbana-em-lisboa. Acesso em: 9 abr. 2019.

ROLNIK, S. O mal-estar na diferença. Núcleo de Estudos da Subjetividade da PUC-SP, 1995. Disponível em: http://www.pucsp.br/nucleodesubjetividade/Textos/SUELY/ Malestardiferenca.pdf. Acesso em: 28 mar. 2018.

SERRES, M. Os cinco sentidos: filosofia dos corpos misturados. Rio de Janeiro: Bertrand, 2001.

SHAPIRO, R.; HEINICH, N. Quando há artificação?. Sociedade e Estado, v. 28, n. 2, p. 14-28, 2013.

SIMÕES, J. Viver (d)o hip-hop: entre o amadorismo e a profissionalização. In: ALMEIDA, M. I. M. de; PAIS, J. M. (org.). Criatividade, juventude e novos horizontes profissionais. Rio de Janeiro: Zahar, 2012. p. 186-209.

VELHO, G. Subjetividade e sociedade: uma experiência de geração. Rio de Janeiro: Jorge Zahar, 1986.

VELHO, G. Antropologia urbana: encontro tradições e novas perspectivas. Sociologia, Problemas e Práticas, n. 59, p. 11-18, 2009. Disponível em: http://www.scielo.mec.pt/ pdf/spp/n59/n59a02.pdf. Acesso em: 12 set. 2018.

WACLAWEK, A. From graffiti to the street art movement: negotiating art worlds, urban spaces, and visual culture, c. 1970-2008. 2008. Tese (Doutorado em Filosofia) - Departament in Art History, Concordia University, Montreal, 2008. Disponível em: http:// spectrum.library.concordia.ca/976281/1/NR63383.pdf. Acesso em: 28 mar. 2015.

Recebido: 21/10/2018 Aceito: 15/04/2019 | Received:10/21/2018 Accepted: 4/15/2019 